\title{
FACTORIAL DESIGN AND OPTIMIZATION OF LEACHATE TREATMENT USING PERSULFATE OXIDATION
}

HILLES A.H. ${ }^{1}$

ABU AMR S.S. ${ }^{2, *}$ *to whom all correspondence should be addressed: e-mail: sabuamr@hotmail.com

\author{
${ }^{1}$ Palestinian Environment Quality Authority \\ Gaza Strip, Gaza, Palestine \\ ${ }^{2}$ Environmental Engineering Technology \\ Malaysian Institute of chemical \& Bioengineering Technology \\ Universiti Kuala Lumpur, (UniKL, MICET), 78000, Melaka, Malaysia
}

Received: 02/06/2016

Accepted: 28/06/2016

Available online: $27 / 10 / 2016$

ABSTRACT

The current study aimed to evaluate the performance of sodium persulfate to treat stabilized landfill leachate. Factorial design with response surface methodology (RSM) was used to evaluate the interaction between operational conditions, such as persulfate dosage, $\mathrm{pH}$, and reaction time, to obtain the optimum conditions. The two quadratic models obtained by RSM for $\mathrm{COD}$ and $\mathrm{NH}_{3}-\mathrm{N}$ removal proved to be significant models $(\mathrm{P}<0.0001)$. The optimum conditions obtained included a reaction time of $60 \mathrm{~min}, 4.97 \mathrm{~g} \mathrm{~S}_{2} \mathrm{O}_{8}{ }^{2-}$, dosage and $\mathrm{pH}$ 7. The experimental results were corresponding well with predicted models (COD and $\mathrm{NH}_{3}-\mathrm{N}$ removal rates of $45 \%$, and $47 \%$, respectively. The results revealed that persulfate oxidation is an efficient for pretreatment of stabilized landfill leachate.

Keywords: landfill leachate, Persulfate, Activation, oxidation.

\section{Introduction}

Disposal of solid waste using sanitary landfilling technology continues to be widely accepted and used because of its economic feasibility. Comparative studies of the various applicable methods in regard reducing the quantity of solid waste (i.e. composting and recycling, landfilling and incineration) have shown that the lowest in cost, in term of investment and capital costs, is landfilling (Qasim and Chiang, 1994).

Leachate is a liquid produced during waste decomposition process (US EPA, 2005; Renou et al., 2008; Cameron and Koch, 1980; Blakey, 1989). The age of landfill in one of the most important factors that effect on leachate characteristics (Kjeldsen and Christophersen, 2001; Poznyak et al., 2008). Accordingly; leachates can be classified in to three main categories based on landfill age: such as young ( $<5$ years), intermediate (between 5 and 10 years) and stabilized (>10 years) (Öman and Hynning, 1993; Kang et al., 2002). By increasing of landfill age, leachate produced is characterized by very hard organic and very low biodegradability which is difficult to treat biologically (Bueno and Bertazzoli, 2005). Different applications on stabilized leachate treatment have been applied such as coagulation-flocculation (O'Melia et al., 1999; Tatsi et al., 2003), chemical precipitation and activated carbon adsorption (Kurniawan et al., 2006), membranes (Osturk et al., 2003; Martinnen et al., 2002), combination of coagulation, flocculation and chemical oxidation

Hilles A.H. and Abu Amr S.S. (2016), Factorial design and optimization of leachate treatment using persulfate oxidation, Global NEST Journal, 18(4), 842-854. 
(Rivas et al., 2004), advanced oxidation (Lopes and Zamora, 2005), ozonation (Abu Amr et al. 2014; Monje and Velasquez, 2004), combination of ozone/Fenton and ozone/persulfate (Abu Amr et al., 2013a; 2013b), biodegradation and adsorption to activated carbon (Welander and Henrysson, 1998) wet air oxidation at high temperature (Rivas et al., 2005), electro-Fenton method (Zhang et al., 2006). The great variety of leachate constituents prevents evaluation of the fate and the role played by each component in the environmental impact.

Recently, persulfate $\left(\mathrm{S}_{2} \mathrm{O}_{8}{ }^{2-}\right)$ emerged as an efficient oxidant for in-situ chemical oxidation (ISCO) applications with the properties of high water solubility, no odor, effectiveness of oxidation over a wide range of $\mathrm{pH}$, and lower affinity for soil organics (Liang et al., 2006). Persulfate can be thermally (Gu et al., 2011; Deng et al., 2013), chemically (Leng et al., 2014), or photo-chemically (Lin et al., 2011) activated to generate the oxidant with high oxidation potential such sulfate radical $\left(\mathrm{SO}_{4}{ }^{-}\right)$, which can efficiently oxidize of most organic contaminants. Persulfate $\left(\mathrm{S}_{2} \mathrm{O}_{8}{ }^{2-}\right)$ was efficiently used for groundwater and soil cleanup (Huling and Pivetz, 2006) and it considered as a strong oxidant with a standard oxidation potential ( $\left.E^{\circ}\right)$ of $2.01 \mathrm{~V}$ (Eq. 1\& 2), (Kolthoff and Stenger, 1947).

$$
\begin{aligned}
& \mathrm{S}_{2} \mathrm{O}_{8}^{2-}+2 \mathrm{e}^{-} \rightarrow \mathrm{SO}_{4}^{-}+\mathrm{SO}_{4}^{-} \\
& \mathrm{SO}_{4}^{-}+\mathrm{H}_{2} \mathrm{O} \rightarrow \mathrm{HSO}_{4}^{-}+\bullet \mathrm{OH}
\end{aligned}
$$

However, the effect of leachate quality especially high organic and ammonia content and high level of heavy metals and trace elements on the performance of persulfate oxidation was not well documented. This study investigated the performance of persulfate oxidation for landfill leachate treatment with high concentration of refractory organic compounds.

\section{Materials and Methods}

\subsection{Leachate Sampling and Characteristics}

Samples of leachate were collected from anaerobic stabilized landfill leachate Deir El-balah sanitary landfill site, Gaza Strip, Palestine.

The landfill has an area of 7 ha, receiving approximately 450 tons of municipal solid waste daily (SWMC, 2012). Leachate samples were collected manually once every week for 4 months between February 2014 and June 2014 and placed in 2 I plastic containers.

In an anaerobic stabilized landfill, solid wastes are decomposed by a conventional municipal method (Matsufuji, 1990). Solid waste is sandwiched by soil. Hudgins and Harper, (1999) reported that anaerobic landfills contain high concentrations of organic compounds and pathogens. The waste mass also slowly degrades, posing long-term risks. The stabilization of landfill is enhanced by leachate recirculation method. The collected samples were immediately transferred to the laboratory, characterized, and stored at cold room $\left(4{ }^{\circ} \mathrm{C}\right)$. General characterization and heavy metals content of the leachate used in the current study was mentioned in Table 1 and 2, respectively. Sampling processes and storage techniques were implemented according to the Standard Methods for the Examination of Water and Wastewater (APHA, 2005).

The average values of heavy metals concentrations in the leachate are given in Table 2. The comparison of these values with the guidelines from EPA (according to water irrigation standards) show that, the concentration of heavy metals ( $\mathrm{Cu}, \mathrm{Pb}, \mathrm{Ni}, \mathrm{Mn}, \mathrm{Cd}$ and $\mathrm{Zn}$ ) in the current leachate exceed the maximum values allowed. 
Table 1. General characteristics of anaerobic stabilized landfill leachate from DBLS

\begin{tabular}{cc}
\hline Parameter & Results \\
\hline COD $\left(\mathrm{mg} \mathrm{l}^{-1}\right)$ & $19,180-20,448 \pm 122.35$ \\
\hline BOD $\left(\mathrm{mg} \mathrm{l}^{-1}\right)$ & $1,821 \pm 35.22$ \\
\hline BOD/COD ratio & $0.09 \pm 0.04$ \\
\hline EC $(\mu \mathrm{s})$ & $40,800 \pm 444.36$ \\
\hline TDS $\left(\mathrm{mg} \mathrm{l}^{-1}\right)$ & $25,296 \pm 247.65$ \\
\hline Nitrate $\left(\mathrm{mg} \mathrm{l}^{-1}\right)$ & $3,602 \pm 12.53$ \\
\hline Ammonia $\left(\mathrm{mg} \mathrm{l}^{-1}\right)$ & $2,478 \pm 3.1$ \\
\hline Chloride $\left(\mathrm{mg} \mathrm{l}^{-1}\right)$ & $6,953 \pm 5.32$ \\
\hline Sulfate $\left(\mathrm{mg} \mathrm{l}^{-1}\right)$ & $856 \pm 2.12$ \\
\hline Alkalinity $\left(\mathrm{mg} \mathrm{l}^{-1}\right)$ & $24,000 \pm 365.24$ \\
\hline Hardness $\left(\mathrm{mg} \mathrm{l}^{-1}\right)$ & $7,283 \pm 6.83$ \\
\hline Calcium $\left(\mathrm{mg} \mathrm{l}^{-1}\right)$ & $1,620 \pm 3.225$ \\
\hline Magnesium $\left(\mathrm{mg} \mathrm{l}^{-1}\right)$ & $785 \pm 4.412$ \\
\hline Potassium $\left(\mathrm{mg} \mathrm{l}^{-1}\right)$ & $4,346 \pm 5.29$ \\
\hline Sodium (mg l-1) & $6,000 \pm 8.98$ \\
\hline $\mathrm{pH}$ & $8.42 \pm 0.04$ \\
\hline Turbidity (NTU) & $538 \pm 3.54$ \\
\hline
\end{tabular}

The order of heavy metals concentration were $\mathrm{Fe}>\mathrm{Zn}>\mathrm{Ni}>\mathrm{Cu}>\mathrm{Cd}>\mathrm{Pb}>\mathrm{Mn}$ from highest to lowest concentration. The presence of these metals in leachate indicated that the variety waste disposal in the site. Alslaibi, (2009) reported considerable amounts of heavy metals in this type of leachate (Table 2).

Table 2. Average heavy metals concentrations of anaerobic stabilized landfill leachate

\begin{tabular}{ccc}
\hline Heavy Metal & Symbol & Concentration( $\left.\mathbf{m g ~ I}^{-\mathbf{1}}\right)$ \\
\hline Copper & $(\mathrm{Cu})$ & $0.44 \pm 0.05$ \\
\hline Lead & $(\mathrm{Pb})$ & $0.143 \pm 0.054$ \\
\hline Nickel & $(\mathrm{Ni})$ & $4.63 \pm 0.8$ \\
\hline Manganese & $(\mathrm{Mn})$ & $0.08 \pm 0.01$ \\
\hline Cadmium & $(\mathrm{Cd})$ & $0.259 \pm 0.03$ \\
\hline Zinc & $(\mathrm{Zn})$ & $5.84 \pm 1.2$ \\
\hline Iron & $(\mathrm{Fe})$ & $48.7 \pm 3.4$ \\
\hline
\end{tabular}

\subsection{Experimental Procedures}

For each run, persulfate reagent as sodium persulfate $\left(\mathrm{Na}_{2} \mathrm{~S}_{2} \mathrm{O}_{8} \mathrm{M}=238 \mathrm{~g} \mathrm{~mol}^{-1}\right)$ was employed for advanced oxidation during the oxidation of leachate samples. Persulfate dosages was determined as $\mathrm{COD} / \mathrm{S}_{2} \mathrm{O}_{8}{ }^{2-}$ ratio $(\mathrm{g} / \mathrm{g})$ with different ratios that gradually added to the leachate to determine the optimum $\mathrm{S}_{2} \mathrm{O}_{8}{ }^{2-}$ dosage according to the efficiencies of $\mathrm{COD}$, and $\mathrm{NH}_{3}-\mathrm{N}$ removal. Orbital Shaker (Luckham R100/TW Rotatest Shaker $340 \mathrm{~mm}$ X $245 \mathrm{~mm}$ ) was used for samples shaking at $350 \mathrm{rpm}$. All experiments were performed at room temperature $\left(28^{\circ} \mathrm{C}\right)$ using $50 \mathrm{ml}$ samples in polyethylene bottles with a $250 \mathrm{~mL}$ capacity. pH was adjusted at the desired values using $5 \mathrm{M}$ sulfuric acid solution and $5 \mathrm{M}$ sodium hydroxide solution.

\subsection{Analytical Methods}

COD and $\mathrm{NH}_{3}-\mathrm{N}$, were examined before and after each run according to Standard Methods for the Examination of Water and Wastewater (APHA, 2005). Leachate was mixed well before analyzed. $\mathrm{NH}_{3}-\mathrm{N}$ concentration was measured by the Phenol Method No. (4500) using a UV-VIS spectrophotometer at $640 \mathrm{~nm}$ with a light path of $1 \mathrm{~cm}$ or greater. $\mathrm{pH}$ was measured using a portable digital $\mathrm{pH} / \mathrm{Mv}$ meter. COD 
concentration was determined by the open reflux method No. (5220). COD measurements have not reported any interference when using high concentration of persulfate dosage. BOD concentration was examined by the 5- Day BOD (5210B) (HACH COMPANY, Loveland CO 80539 USA). Total Dissolved Solids were measured by TDS Dried at $180{ }^{\circ} \mathrm{C}$ method (2540C). The electrical Conductivity (EC) was measured as $\mu \mathrm{cm}^{-1}$ using a portable multi-purpose apparatus (Senslon7, Conductivity Meter, HACH Company, BOX 389/ Loveland, Colo. USA). Turbidity was measured using Nephelometry method by Turbidometer (HACH 2100AN). Nitrate was tested by using Ultraviolet Spectrophotometric Screening Method (4500- NO3 -B). Chloride was determined using Argentometric Method (4500-Cl-B). Sulfate was measured using Turbidimetric Method (4500-SO4 -2E). Alkalinity was measured by applying Titration Method (2320 Alkalinity method B). Hardness was tested using EDTA Titrimetric Method (2340C). Calcium was determined using EDTA Titrimetric Method (3500-Ca B). Magnesium was tested using Calculation Method (3500-Mg B). Potassium was tested using Flame Photometric Method (3500-K B) (Sherwood FP 410). Sodium was measured using Flame Emission Photometric Method (3500-Na B). Heavy metals concentration was determined using Atomic Absorption Spectroscopy (AAS). The removal efficiencies of $\mathrm{COD}$ and $\mathrm{NH}_{3}-\mathrm{N}$ were obtained using the following equation (3):

$$
\text { Removal }(\%)=\left[\left(X_{i}-X_{f}\right) / X_{i}\right] \times 100
$$

Where $X_{i}$ and $X_{f}$ refer to the initial and final COD and $\mathrm{NH}_{3}-\mathrm{N}$ concentrations respectively.

\subsection{Experimental Design and Analysis}

Factorial design of expert software (version 6.0.7) with RSM was utilized for the statistical and interaction of the experiments. Optimization of the experimental factors and responses were applied to investigate the relationships between the three independent factors, as presented in Table 3: (1) persulfate dosage, (2) pH variation, and (3) reaction time.

Table 3. Coded values for independent factors, (Persulfate oxidation)

\begin{tabular}{cccc}
\hline Level of Value & Persulfate $\left((\mathrm{g} / \mathrm{g}) \mathrm{COD} / \mathbf{S}_{\mathbf{2}} \mathbf{O}_{\mathbf{8}}\right)$ & $\mathbf{p H}$ & Reaction time (min) \\
\hline-1 & 1.4 & 3 & 30 \\
\hline 0 & 2.8 & 5 & 45 \\
\hline+1 & 4.2 & 7 & 60 \\
\hline
\end{tabular}

The Performance of persulfate oxidation was determined by determine the COD and $\mathrm{NH}_{3}-\mathrm{N}$ removal efficiencies. The levels of values for each factor were determined based on a set of preliminary experiments. The total number of experiments conducted for the three factors was $20\left(=2^{k}+2 k+6\right.$, where $k$ is the number of factors=3); to estimate the pure error, 14 experiments were supported with six replications. Quadratic model was performed following Eq. 4:

$$
Y=\beta_{0}+\sum_{j=1}^{k} \beta_{j} X_{j}+\sum_{j=1}^{k} \beta_{j j} x_{j}^{2}+\sum_{i} \sum_{<j=2}^{k} \beta_{i j} X_{i} X_{j}+e_{i}
$$

where $Y$ is the response, $X_{i}$ and $X_{j}$ are the variables, $\beta$ is the regression coefficient, $k$ is the number of factors studied and optimized in the experiment, and $\mathrm{e}$ is the random error.

\section{Results and Discussion}

In order to obtain an optimal $\mathrm{S}_{2} \mathrm{O}_{8}{ }^{2-}$ dosage; a total of 20 experiments were performed using different dosage of persulfate $\left(\mathrm{COD} / \mathrm{S}_{2} \mathrm{O}_{8}{ }^{2-}(\mathrm{g} / \mathrm{g})\right)$ ratio, reaction time $(\mathrm{min})$ and $\mathrm{pH}$ at room temperature $\left(28{ }^{\circ} \mathrm{C}\right)$ and the results was presented in Table 4. The performance of $\mathrm{S}_{2} \mathrm{O}_{8}{ }^{2-}$ in treating anaerobic stabilized leachate was investigated in term of COD and ammonia removal efficiency. The results show increasing of removal efficiency of COD 
and ammonia as the dosage of $\mathrm{S}_{2} \mathrm{O}_{8}{ }^{2-}$ is increase. As shown in table 4; the removal of COD ranges between $10 \%$ and $44 \%$, while the ammonia removal ranged between $3 \%$ and $47 \%$. The maximum removal efficiency for both $\mathrm{COD}$ and ammonia was obtained at $1 / 40\left(\mathrm{COD} / \mathrm{S}_{2} \mathrm{O}_{8}{ }^{2-} \mathrm{g} / \mathrm{g}\right), \mathrm{pH}=7$ and 60 min reaction time.

Table 4. Matrix value for different experimental conditions with $\mathrm{COD}$ and $\mathrm{NH}_{3}-\mathrm{N}$ removal (Persulfate oxidation)

\begin{tabular}{|c|c|c|c|c|c|}
\hline & Factor 1 & Factor 2 & Factor 3 & Response 1 & Response 2 \\
\hline Run & $\begin{array}{c}\text { A:Persulfate } \\
\left((\mathrm{g} / \mathrm{g}) \mathrm{COD} / \mathrm{S}_{2} \mathrm{O}_{8}\right)\end{array}$ & B:pH & C:RT (min) & COD removal (\%) & $\mathrm{NH}_{3}-\mathrm{N}$ removal (\%) \\
\hline 1 & 2.80 & 8.36 & 45.0 & 29.2 & 25.6 \\
\hline 2 & 1.40 & 3.00 & 30.0 & 28.5 & 10.0 \\
\hline 3 & 4.20 & 7.00 & 30.0 & 29.0 & 32.4 \\
\hline 4 & 1.40 & 3.00 & 60.0 & 31.0 & 8.00 \\
\hline 5 & 4.20 & 3.00 & 30.0 & 28.0 & 28.0 \\
\hline 6 & 0.440 & 5.00 & 45.0 & 25.0 & 3.00 \\
\hline 7 & 4.20 & 7.00 & 60.0 & 44.6 & 47.6 \\
\hline 8 & 1.40 & 7.00 & 30.0 & 10.0 & 3.00 \\
\hline 9 & 2.80 & 5.00 & 45.0 & 32.2 & 25.1 \\
\hline 10 & 5.15 & 5.00 & 45.0 & 42.0 & 37.0 \\
\hline 11 & 2.80 & 5.00 & 70.2 & 33.0 & 28.0 \\
\hline 12 & 1.40 & 7.00 & 60.0 & 17.0 & 7.50 \\
\hline 13 & 2.80 & 5.00 & 45.0 & 32.5 & 25.8 \\
\hline 14 & 2.80 & 1.64 & 45.0 & 37.0 & 24.0 \\
\hline 15 & 2.80 & 5.00 & 45.0 & 31.7 & 26.1 \\
\hline 16 & 2.80 & 5.00 & 45.0 & 32.3 & 25.7 \\
\hline 17 & 2.80 & 5.00 & 45.0 & 31.9 & 25.4 \\
\hline 18 & 4.20 & 3.00 & 60.0 & 34.0 & 31.4 \\
\hline 19 & 2.80 & 5.00 & 45.0 & 32.1 & 26.2 \\
\hline 20 & 2.80 & 5.00 & 19.8 & 18.4 & 21.0 \\
\hline
\end{tabular}

The results compared with the study achieved by Deng and Casey (2011) used persulfate dosage $\left(\mathrm{S}_{2} \mathrm{O}_{8}{ }^{2-}: 12 \mathrm{COD}_{0}=0.1: 2\right)$. The study reported $55 \%$ removal for $\mathrm{COD}$ at $50{ }^{\circ} \mathrm{C}$. Although several literatures reported different applications in activation of persulfate to enhance its powerful oxidation by release sulfate radicals; such as heat, UV, ozone, Iron ions and high pH (Shiying et al., 2009; Abu Amr et al., 2013a; Lin et al., 2011; Furman et al., 2011; Rastogi et al., 2009; Hung et al., 2002; Gao et al., 2012), however, persulfate can be act alone as a good oxidant and can be efficiently activated with the existing of natural clay menials and inorganic components in leachate (Block et al., 2004). Furthermore, the high level of heavy metals and trace elements found in leachate can be tack place in naturally activation of persulfate. Ahmad et al., (2010) investigated the effect of Iron and manganese oxide found in natural soil on persulfate activation. When persulfate mixed with iron (II), it is capable of forming the sulfate radical $\left(\mathrm{SO}_{4}{ }_{4}^{-}\right)$that has an even higher redox potential ( $E^{\circ}=2.6 \mathrm{~V}$ ) (Killian et al., 2007). Rastogi et al., (2009) explained the effects of iron ions on persulfate activation (Eq. $5 \& 6$ )

$$
\begin{aligned}
& \mathrm{Fe}^{3+}+\mathrm{S}_{2} \mathrm{O}_{8}^{2-} \rightarrow 2 \mathrm{SO}_{4}^{--}+\mathrm{Fe}^{2+} \\
& \mathrm{Fe}^{2+}+\mathrm{SO}_{4}^{--} \rightarrow \mathrm{Fe}^{3+}+\mathrm{SO}_{4}^{2-}
\end{aligned}
$$


Iron ions in leachate can play a significant role in enhance of persulfate oxidation. In the study that was implemented by Killian et al., (2007), they found that the lower iron concentration in soil could be used as a persulfate activator to reduce the consumption of persulfate and to increase the organic degradation of contaminants. It means that the time and the presence of iron as one of the predominant heavy metals found in the current leachate samples will enhance the treatment processes and the organic removal efficiency.

Tan et al., (2012) achieved high level of diuron reduction in aqueous solution used Iron ions for persulfate activation. Li et al., (2014) employed Zero valent $\mathrm{Zn}^{\circ}$ in activation of persulfate for degradation of methyl orange. The studied leachate reported $48.7 \mathrm{mg} \mathrm{l}^{-1}, 0.08 \mathrm{mg} \mathrm{l}^{-1}$ and $5.84 \mathrm{mg} \mathrm{l}^{-1}$ for Iron, Manganese and Zinc, respectively (Table 2 ).

Moreover, the removal efficiencies for COD and ammonia were increased by increasing the $\mathrm{pH}$. At high $\mathrm{pH}$ conditions, alkaline activation is very productive in generating sulfate and hydroxyl radicals. Both radicals $\left(\mathrm{SO}_{4}^{-}\right.$and $\left.\mathrm{OH}^{\circ}\right)$ have high oxidation potential $\left(E^{\circ}=2.80\right.$ and $E^{\circ}=2.70$, respectively) (House, 1962). The effect of alkalinity on persulfate oxidation has been reported (Furman et al., 2011; Ocampo, 2009). At high pH value, hydroxyl radical can be act to activate persulfate and initiate sulfate radical (Eq. 7)

$$
\mathrm{S}_{2} \mathrm{O}_{8}^{2-}+\mathrm{OH}^{-} \rightarrow \mathrm{HSO}_{4}^{-}+\mathrm{SO}_{4}^{2-}+1 / 2 \mathrm{O}_{2}
$$

Even though the optimal removal efficiency in the present study was obtained at the optimal temperature of $28{ }^{\circ} \mathrm{C}$ and $\mathrm{pH}$ (7), significant removal efficiency was obtained also at low pH (3 - 4) (Fig.2). Deng and Ezyske (2011) obtained higher removal of $\mathrm{COD}$ and $\mathrm{NH}_{3}-\mathrm{N}$ from leachate at low $\mathrm{pH}$ (4) using persulfate alone. Shabiimam and Dikshit (2012) reported lower organic removal in stabilized leachate at acidic medium (pH 2.5) using sodium persulfate reaction. Furthermore, Lin et al. (2011) obtained the best removal of Phenol from wastewater at high $\mathrm{pH}$ (11) using UV for persulfate activation.

\subsection{Analysis of Variance (ANOVA)}

Table 5 presents the statistical parameters of ANOVA regression for the predicted models for $\mathrm{COD}$ and $\mathrm{NH}_{3}-$ $\mathrm{N}$ removal. The data given in this table demonstrate that all of the models were significant at a $5 \%$ confidence level, given that the $P$ values were less than 0.05 . The coefficient of determination $\left(R^{2}\right)$ for $C O D$ and $N_{3}-N$ removal $\left(R^{2}=0.970\right.$ and 0.972 respectively). $\left(R^{2}=0.9236\right.$, and 0.9062 , respectively) were higher than 0.80 . A high $R^{2}$ value illustrates good agreement between the predicted and experimental results and shows that a desirable and reasonable agreement with the adjusted $R^{2}$ (Nordin et al., 2004). The "adequate precision" (AP) ratio of the two models are 25.4, which is adequate. AP values above 4 are desirable and confirm that the predicted models can be used to navigate the space defined by the central composite design (CCD). The Model F-value for COD and Ammonia removal of 35.86 and 38.9, respectively, implies the models are significant. The lack of Fit was statistically significant with F-value of 87.01 and 79.01 for COD and Ammonia removal, respectively with $p$ value of $<0.0001$.

The final regression models, in terms of coded factors, are presented in Eqs. (8\&9).

$$
\begin{aligned}
& \text { COD removal }(\%)=70.0+18.8 * A+41.6 * B+16.2 * C-3.00 * A^{2}-0.270 * B^{2}-2.89 * C^{2}+27.6 * A * B+7.56 * A * C+1.76 * B * C \\
& \mathbf{N H}_{3}-\mathbf{N} \text { removal }(\%)=-30.3-132 .{ }^{*} A+29.3 * B+18.5 * C-60.4 * A^{2}-0.739 * B 2-0.845 * C+17.6 * A * B+10.1 * A * C+2.29 * B * C
\end{aligned}
$$

Normal probability plots of the standardized residuals and diagnostics of $\mathrm{COD}$ and $\mathrm{NH}_{3}-\mathrm{N}$ removal were confirmed that the selected models provided suitable similarity of the real design and demonstrate the normal probability plots for the standardized residuals (Fig 1). The relationship between experimental and predicted results of $\mathrm{COD}$ and $\mathrm{NH}_{3}-\mathrm{N}$ removals is illustrated in Fig. 1. It can be seen that the predicted and experimental values arranged along with the fit line indicating that the predicted and experimental values were in high reasonable agreement (Fig 1). 
COD removal (\%)
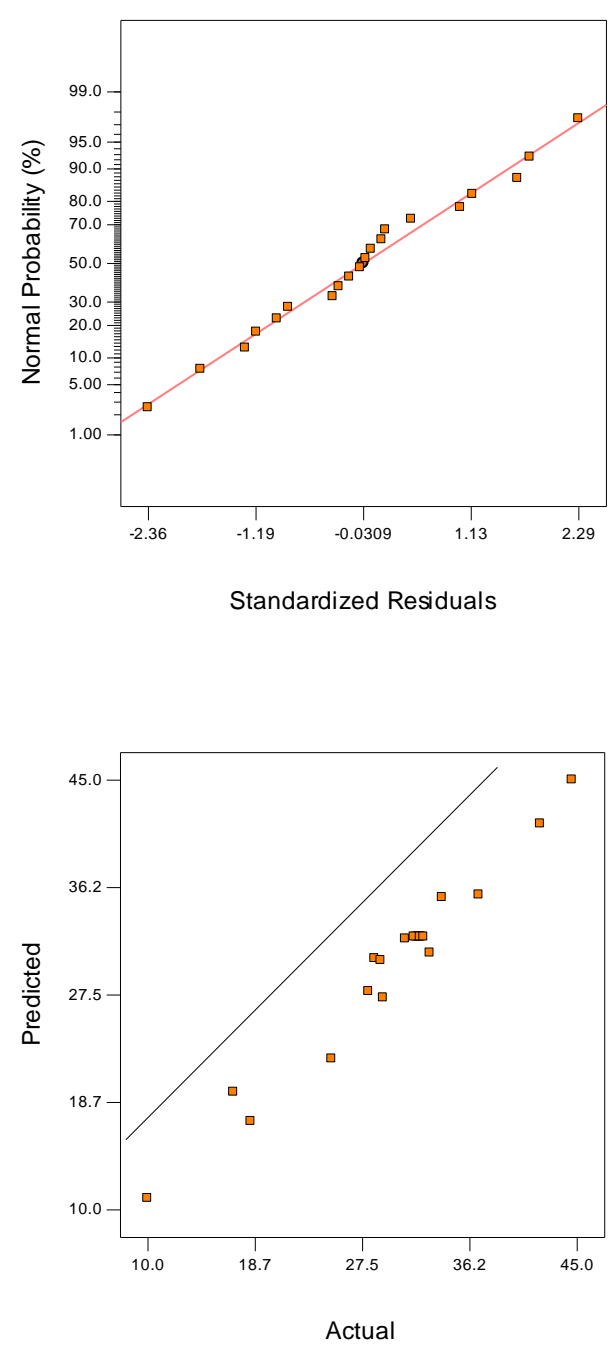

NH3-N removal (\%)
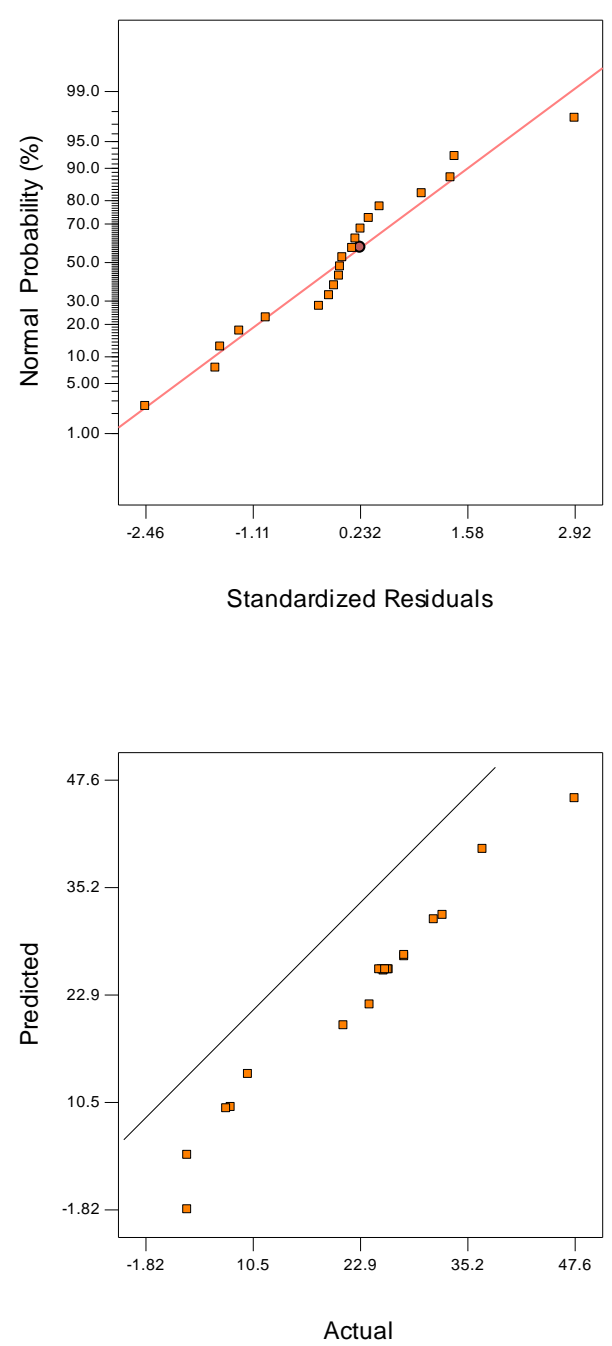

Figure 1. Design Expert plot; normal probability plot of the standardized residual and Actual versus predicted removal of $\mathrm{COD}$ and $\mathrm{NH}_{3}-\mathrm{N}$

\subsection{Treatment Efficiency and Optimization Process}

To determine the interaction between independent factors and the responses, 3D surface response plots were performed by Design Expert 6.0.7 software. The maximum removal of COD and $\mathrm{NH}_{3}-\mathrm{N}$ were $45 \%$ and $47 \%$, respectively (Fig. 2). The maximum removal value for $\mathrm{COD}$ and $\mathrm{NH}_{3}-\mathrm{N}$ was obtained at maximum persulfate dosage of $5.15 \mathrm{~g}, \mathrm{pH} 7$ and reaction time $60 \mathrm{~min}$. The maximum persulfate dosage at natural $\mathrm{pH}$ (7) resulted in the formation of hydroxyl and sulfate radicals, which is considered as a further improvement of the oxidation process efficiency. However, excess amount of sulfate ions participate in consuming an amount of hydroxyl radical. This condition inhibits a part of the oxidation and decreases the efficiency of the compound pollutants elimination in the treatment process (Tizaou et al., 2007). Deng and Ezyske (2011) 
observed the same results when used sulfate radical for leachate treatment. The interaction between $\mathrm{pH}$ and persulfate is illustrated in Figs 2.

Table 5. ANOVA and adequacy of the quadratic model for $\mathrm{COD}$ and $\mathrm{NH}_{3}-\mathrm{N}$

\begin{tabular}{|c|c|c|c|c|c|c|c|}
\hline \multirow{16}{*}{ 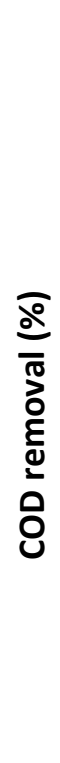 } & & Sum of & & Mean & $\mathbf{F}$ & & \\
\hline & Source & Squares & DF & Square & Value & Prob> F & \\
\hline & Model & $1.16 \mathrm{E}+003$ & 9 & 129. & 35.9 & $<0.0001$ & significant \\
\hline & $\mathrm{A}$ & 0.797 & 1 & 0.797 & 0.222 & 0.648 & \\
\hline & $\mathrm{B}$ & 214. & 1 & 214. & 59.7 & $<0.0001$ & \\
\hline & $\mathrm{C}$ & 32.4 & 1 & 32.4 & 9.02 & 0.0133 & \\
\hline & $\mathrm{A} 2$ & 0.207 & 1 & 0.207 & 0.0576 & 0.815 & \\
\hline & B2 & 1.05 & 1 & 1.05 & 0.293 & 0.600 & \\
\hline & $\mathrm{C} 2$ & 120. & 1 & 120. & 33.4 & 0.000178 & \\
\hline & $A B$ & 243. & 1 & 243. & 67.6 & $<0.0001$ & \\
\hline & $A C$ & 18.3 & 1 & 18.3 & 5.09 & 0.0476 & \\
\hline & $\mathrm{BC}$ & 24.9 & 1 & 24.9 & 6.92 & 0.0252 & \\
\hline & Residual & 35.9 & 10 & 3.59 & & & \\
\hline & Pure Error & 0.408 & 5 & 0.0817 & & & \\
\hline & Cor Total & $1.20 \mathrm{E}+003$ & 19 & & & & \\
\hline & Lack of Fit & 35.53 & 5 & 7.11 & 87.01 & $<0.0001$ & significant \\
\hline
\end{tabular}

Std. Dev.:1.90; R²: 0.970; Mean: 30.0; Adj R²: 0.943; C.V.: 6.33; Pred R²: 0.770; PRESS: 275;

Adeq Precision: 25.4

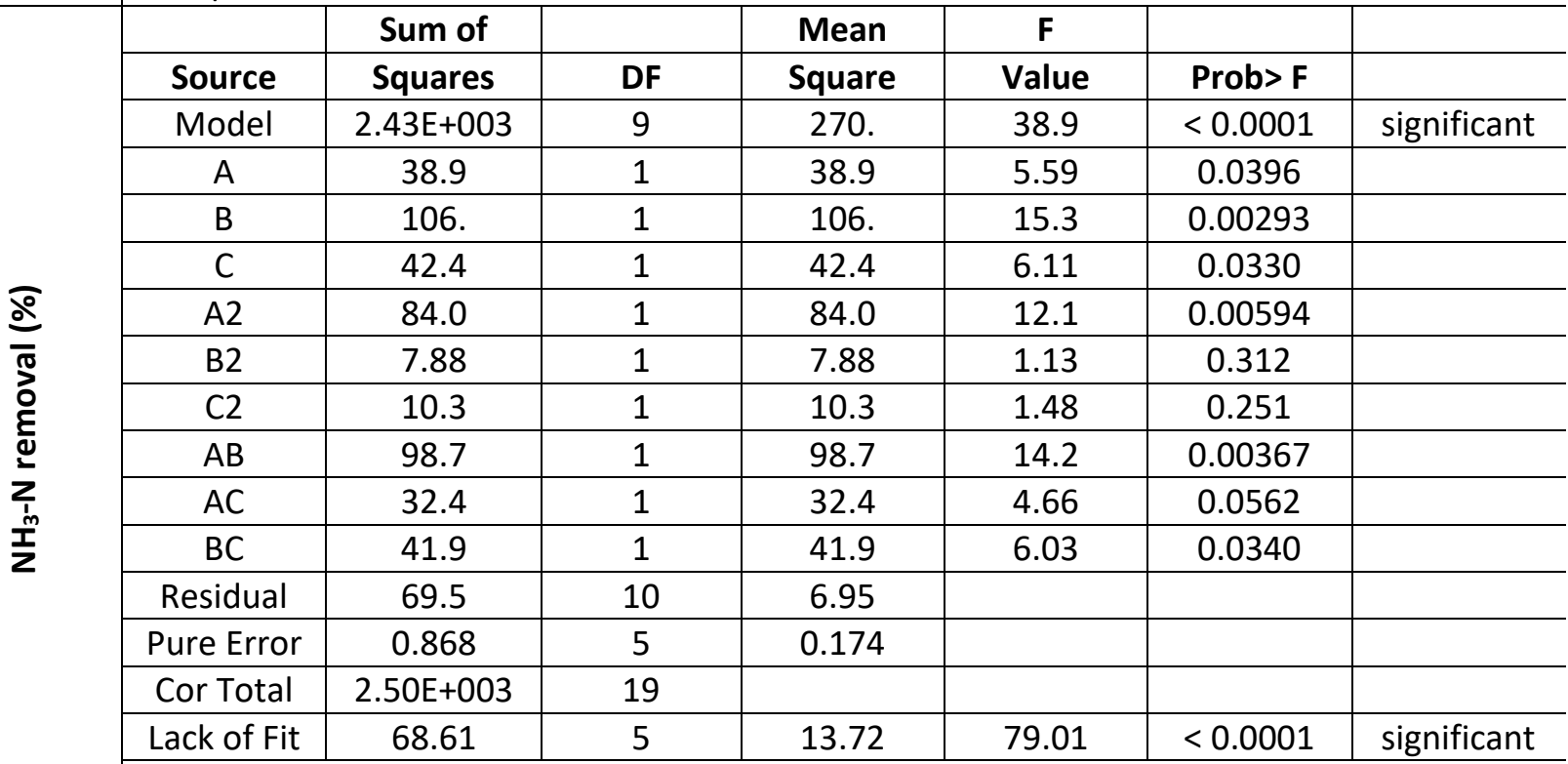

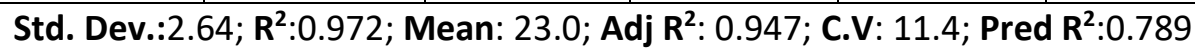

PRESS: 529.; Adeq Precision: 25.4

Optimization was performed to determine optimum removal of $\mathrm{COD}$ and $\mathrm{NH}_{3}-\mathrm{N}$. According to the optimization step, the desired goal for each operational condition (i.e., persulfate dosage, reaction time and $\mathrm{pH}$ ) was chosen "within" the range. $\mathrm{COD}$ and $\mathrm{NH}_{3}-\mathrm{N}$ removal were selected as maximum to achieve the highest removal for $\mathrm{COD}$ and $\mathrm{NH}_{3}-\mathrm{N}$. The optimum conditions established by software and respective removal efficiencies are presented in Table 6: around $46 \%$ and $48 \%$ removal of COD and $\mathrm{NH}_{3}-\mathrm{N}$ are predicted, respectively based on the model and under optimized operational conditions. An additional laboratory experiment was then performed to confirm optimum results. The said conducted laboratory experiments 
were agreed with the predicted response, and values with $45 \%$ and $47 \%$ removal efficiency of COD and $\mathrm{NH}_{3}{ }^{-}$ $\mathrm{N}$ are obtained, respectively.

\section{COD removal (\%)}
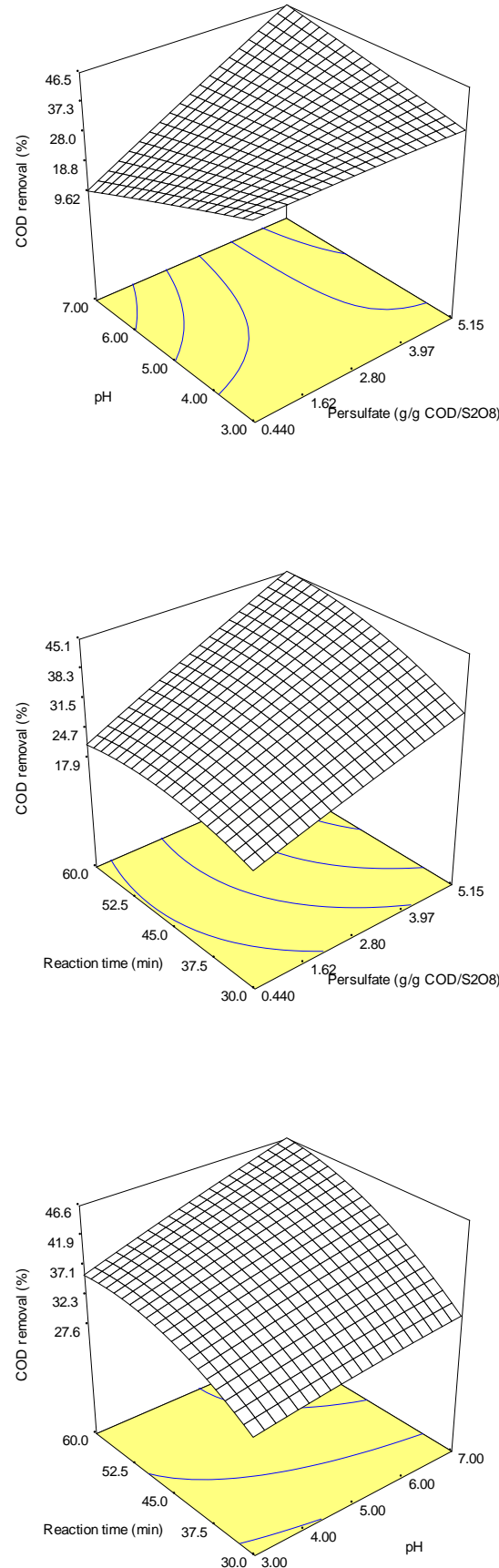

\section{NH3-N removal (\%)}
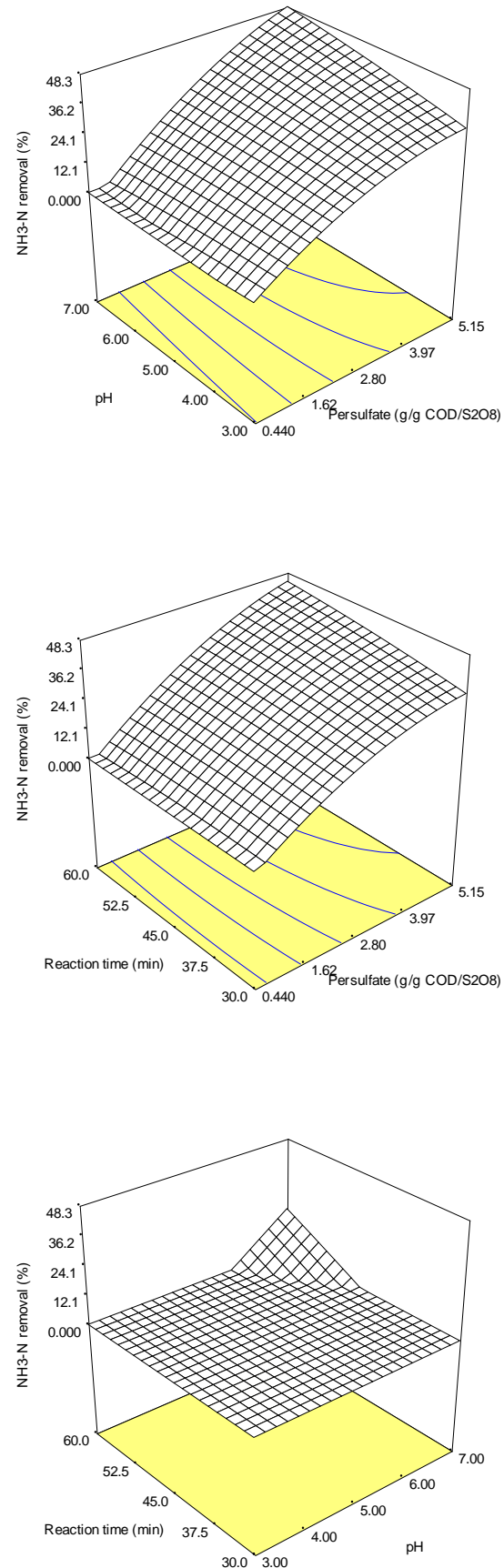

Figure 2. Response surface for $\mathrm{COD}$ and $\mathrm{NH}_{3}-\mathrm{N}$ removal efficiency as a function of persulfate dosage, (5.15), $\mathrm{pH}$ (7) and Reaction time, (60) min 
Table 6. Optimization results for $\mathrm{COD}$ and $\mathrm{NH}_{3}-\mathrm{N}$ maximum removal efficiency.

\begin{tabular}{ccccccc}
\hline Persulfate (g) & $* \mathrm{RT}(\mathrm{min})$ & $\mathbf{p H}$ & $\begin{array}{c}\text { COD } \\
\text { removal (\%) }\end{array}$ & $\begin{array}{c}\text { Ammonia } \\
\text { removal (\%) }\end{array}$ & $\begin{array}{c}\text { Color } \\
\text { removal (\%) }\end{array}$ & Desirability \\
\hline 5.15 & 7 & 11 & 46 & 48 & - & \multirow{2}{*}{1} \\
\hline Lab. Experment & & 45 & 47 & 78 & \\
\hline
\end{tabular}

*RT: Reaction Time

\section{Conclusions}

In this study, the performance of persulfate oxidation for the treatment of solid waste leachate was investigated. The optimum conditions for the treatment were conducted with respect to operational conditions, namely, $\mathrm{S}_{2} \mathrm{O}_{8}{ }^{2-}$ concentration $(5.15 \mathrm{~g}), \mathrm{pH}(7)$ variation, and reaction time (60 min). The maximum removal efficiency for COD and NH3-N was $45 \%$ and $47 \%$, respectively. The results concluded that persulfate reagent can be used efficiently for pretreatment of high concentrated leachate.

\section{Acknowledgment}

The authors wish to acknowledge the staff in Public Health Laboratory at the Ministry of Health- Palestine, solid waste management council and the Municipality of Deir El-balah for facilitating and supporting the implementation of the present work.

\section{References}

Abu Amr S.S., Aziz H.A., Adlan M.N. and Alkaseeh J.M. (2014), Effect of Ozone and Ozone/Persulfate Processes on Biodegradable and soluble characteristics of Semi-aerobic Stabilized Leachate, Journal of environmental progress and sustainable energy, 33, 184-191.

Abu Amr S.S., Aziz H.A., Adlan M.N. and Bashir M.J.K. (2013a), Pretreatment of stabilized leachate using Ozone/Persulfate oxidation process, Chemical Engineering Journal, 221, 492 - 499.

Abu Amr S.S, Aziz H.A. and Adlan M.N. (2013b), Optimization of stabilized leachate treatment using ozone/persulfate in the advanced oxidation process, Waste Management, 33, 1434-1441.

Abu Amr S.S., Aziz H.A., Adlan M.N. and Aziz S.Q. (2013c), Effect of Ozone and Ozone/Fenton in the advanced oxidation process on Biodegradable Characteristics of Semiaerobic Stabilized Leachate. WILEY-VCH Verlag GmbH \& Co. KGaA, Weinheim, Clean: Soil, Air, Water, 41(2), 148-152.

Adeolu A.O., Ada O.V., Gbenga A.A. and Adebayo O.A. (2011), Assessment of groundwater contamination by leachate near a municipal solid waste landfill, African Journal of Environmental Science and Technology, 5(11), 933-940.

Ahmad M., Teel A.L. and Watts R.J. (2010), Persulfate activation by subsurface minerals, Journal of Contaminant Hydrology, 115(1-4), 34-45.

Al Raisi S.A., Sulaiman H., Suliman F. and Abdallah O. (2014), Assessment of Heavy Metals in Leachate of an Unlined Landfill in the Sultanate of Oman, International Journal of Environmental Science and Development, 5, 60-63.

Alslaibi T. (2009), Evaluating the Impact of Landfill Leachate on Groundwater Aquifer in Gaza Strip Using Modeling Approach. (Master Thesis) The Islamic University - Gaza - Palestine.

Aucott M. (2006), The fate of heavy metals in landfills: A Review, New York academy of sciences.

Berlin A.A. (1986), Kinetics of radical-chain decomposition of persulfate in aqueous solutions of organic compounds, Kinetics and Catalysis, 27, 34-39.

Bila D.M., Montalvao A.F. and Silva A.C. and Dezotti M. (2005), Ozonation of landfill leachate: evaluation of toxicity removal and biodegradability improvement, Journal of Hazardous Materials B, 117, 235-242. 
Blakey N.C. (1989), Model prediction of landfill leachate production, in: T.H. Christensen, R. Cossu, R. Stegmann (Eds.), Sanitary Landfilling: Process, Technology and Environment Impact, Academic Press, San Diego, CA.

Block P.A., Brown R.A. and Robinson D. (2004), "Novel activation technologies for sodium persulfate in situ chemical oxidation." 4th Int. Conf. on the Remediation of Chlorinated and Recalcitrant Compounds, Battelle, Monterey, CA

Bookter T.J. and Ham R.K. (1982), Stabilization of solid waste in landfills, Journal of Environmental Engineering, 108, 1089-1100.

Bozkurt S., Moreno L. and Neretnieks I. (2000), Long-term processes in waste deposits, The Science of the Total Environment, 250, 101-121.

Bueno P.M. and Bertazzoli R. (2005), Electrodegradation of landfill leachate in a flow electrochemical reactor, Chemosphere, 58, 41-46.

Deng J., Shao Y., Gao N., Deng Zhou Y.S. and Hu X. (2013), Thermally activated persulfate (TAP) oxidation of antiepileptic drug carbamazepine in water, Chemical Engineering Journal, 228, 765-771.

Deng Y. and Casey M.E. (2011), Sulfate radical-advanced oxidation process (SR-AOP) for simultaneous removal of refractory organic contaminants and ammonia in landfill leachate, Water Research, 45, 6189-6194.

Furman O., Teel A., Ahmad M. and Merker M. and Watts R. (2011), Effect of Basicity on Persulfate Reactivity, Journal of Environmental Engineering, 137(4), 241-247.

Gao Y., Gao N., Deng Y., Yang Y. and Ma Y. (2012), Ultraviolet (UV) light-activated persulfate oxidation of sulfamethazine in water, Chemical Engineering Journal, 195-196, 248-253.

Geenens D., Bixio B. and Thoeye C. (2001), Combined ozone-activated sludge treatment of and fill leachate, Water Science and Technology, 2, 359-365.

Gu X. G., Lu S.G. and Li L. (2011), Oxidation of 1,1,1-trichloroethane stimulated by thermally activated persulfate, Industrial and Engineering Chemistry Research, 50(19), 11029-11036.

Huang K.C., Couttenye R.A. and Hoag G.E. (2002), Kinetics of heat-assisted persulfate oxidation of methyl tert-butyl ether (MTBE), Chemosphere, 49, 413-420.

Huie R.E., Clifton C.L. and Neta P. (1991), Electron transfer reactionrates and equilibria of the carbonate and sulfate radicalanions, Radiation Physics and Chemistry, 38, 477-481.

Huling S.G. and Pivetz B.E. (2006). In-situ Chemical Oxidation (EPA/600/R-06/072).US EPA.

Imai A., Onuma K., Inamori Y. and Sudo R. (1998), Effects of Pre-Ozonation in Refractory Leachate Treatment by the Biological Activated Carbon Fluidized Bed Process, Environmental Technology, 19, 213-221.

Kang K.H., Shin S.H. and Park H. (2002), Characterization of humic substances present in landfill leachates with different landfill ages and its implications, Water Research, 36(16), 4023-4032.

Kanmani S. and Gandhimathi R. (2013), Assessment of heavy metal contamination in soil due to leachate migration from an open dumping site, Applied Water Science, 3, 193-205.

Kesson M.A. and Nilsson P. (1997), Seasonal changes of leachate production and quality from test cells, J. Environ. Eng., 123, 892-900.

Kjeldsen P., Grundtvig A.A., Winther P. and Andersen J.S. (1998), Characterization of an old municipal landfill (Grindsted, Denmark) as a groundwater pollution source: landfill history and leachate composition, Waste Managemement and Research, 16(1), 3-13.

Kjeldsen P., Barlaz M.A., Rooker A.P., Baun A. and Ledin A. and Christensen T.H. (2002), Present and long-term composition of MSW landfill leachate: a review, Critical Reviews in Environmental Science and Technology, 32(4), 297-336.

Kjeldsen P. and Christophersen M. (2001), Composition of leachate from old landfills in Denmark, Waste Management and Research, 19, 249-256.

Kolthoff I.M. and Stenger V.A. (1947). Volumetric Analysis, SecondRevised Ed Titration Methods: Acid-base, Precipitation, andComplex Reactions, vol. II. Interscience Publishers, Inc., NewYork. 
Kurniawan T.A., Lo W.H. and Chan G.Y.S. (2006), Physico-chemical treatments for removal of recalcitrant contaminants from landfill leachate, Journal of Hazardous Materials B, 129, 80-100.

Leng Y., Guo W. and Shi X. (2014), Degradation of Rhodamine B by persulfate activated with $\mathrm{Fe}_{3} \mathrm{O}_{4}$ : effect of polyhydroquinone serving as an electron shuttle, Chemical Engineering Journal, 240, 338-343.

Li H., Guo J., Yang L. and Lan Y. (2014), Degradation of methyl orange by sodium persulfate activated with zero-valent zinc, Separation and Purification Technology, 132, 168-173.

Liang C., Wang Z.S. and Mohanty N. (2006), Influences of carbonate and chloride ions on persulfate oxidation of trichloroethylene at $20^{\circ} \mathrm{C}$, Science of the Total Environment, 370(2-3), 271-277.

Lin Y.T., Liang C. and Chen J.H. (2011), Feasibility study of ultraviolet activated persulfate oxidation of phenol, Chemosphere, 82, 1168-1172.

Lopes de Morais J. and Zamora P.P. (2005), Use of advanced oxidation processes to improve the biodegradability of mature landfill leachates, Journal of Hazardous Materials $B, 123,181-186$.

Martinnen S.K., Kettunen R.H., Sormunen K.M., Soimasuo R.M. and Rintala J.A. (2002), Screening of physical-chemical methods for removal of organic material, nitrogen and toxicity from low strength landfill leachates, Chemosphere, 46, 851-858.

McBean E.A., Rovers F.A. and Farquhar G.J. (1995).Solid Waste Landfill Engineering and Design, Prentice Hall PTR, Englewood Cliffs, NJ.

Mejbri R., Matejka G., Lafrance P. and Mazet M. (1995), Fractionnement et characterisation de la matiereorganique des lixiviats de dechrgesd'orduresmenageres, Revue des Sciences de l'eau, 8(2), 217-236.

Monje I.R. and Orta de Velasquez M.T. (2004), Removal and transformation of recalcitrant organic matter from stabilized saline landfill leachate by coagulation-ozonation coupling processes, Water Research, 38(9), 2359-2367.

Moturi M.Z., Rawat M. and Subramanian V. (2004), Distribution and fractionation of heavy metals in solid waste from selected sites in the industrial belt of Delhi, Environmental Monitoring and Assessment, 95,183-199.

Nanny M.A. and Ratasuk N. (2002), Characterization and comparison of hydrophobic neutral and hydrophobic acid dissolved organic carbon isolated from three municipal landfill leachates, Water Research, 36, 1572-1584.

Nordin M.Y., Venkatesh V.C., Sharif S., Elting S. and Abdullah A. (2004), Application of response surface methodology in describing the performance of coated carbide tools when turning AISI 104 steel, Journal of Materials Processing Technology, 145, 46-58.

O'Melia C.R., Becker W.C. and Au K.K. (1999), Removal of substances by coagulation, Water Science and Technology, 40(9), 47-54.

Ocampo A.M. (2009), Persulfate activation by organic compounds, PhD thesis, Washington state university, Department of Civil and Environmental Engineering. 1- 77.

Osturk I., Altinbas M., Koyuncu I., Arikan O. and Gomec-Yangin C. (2003), Advances physicochemical treatment experiences on yang municipal landfill leachates, Waste Management, 23, 441-446.

Paxeus N. (2000), Organic compounds in municipal landfill leachates, Water Science and Technology, 42(7-8), 323-333.

Poznya K.G., Bautista L., Isaac R., Ivan Córdova L. and Elvira R. (2008), Decomposition of toxic pollutants in landfill leachate by ozone after coagulation treatment, Journal of Hazardous Materials, 152, 1108-1114.

Qasim S.R. and Chiang W. (1994). Sanitary Landfill Leachate: Generation, Control and Treatment, Technomic Publishing, Lancaster, PA.

Rastogi A., Al-Abed S.R. and Dionysiou D.D. (2009), Sulfate radical-based ferrous peroxymonosulfate oxidative system for PCBs degradation in aqueous and sediment systems, Applied Catalysis B: Environmental, 85, 171-179.

Reinhart D.R. and Townsend T.G. (1998), Landfill Bioreactor Design and Operation, CRC Press, Lewis Publishers, Boca Raton, FL.

Renou S., Givaudan J.G., Poulain S., Dirassouyan F. and Moulin P. (2008), Review: Landfill leachate treatment: Review and opportunity, Journal of Hazardous Materials, 150, 468-493 
Rivas F.J., Beltrán F., Carvalho F., Acedo B. and Gimeno O. (2004), Stabilized leachates: sequential coagulationflocculation + chemical oxidation process, Journal of Hazardous Materials B, 116, 95-102.

Rivas F.J., Beltran F.J. and Carvalho F.P. (2005). Alvarez, M., Oxone-promoted wet air oxidation of landfill leachates, Ind. Eng. Chem. Res., 44, 749-758.

Shabiimam M.A. and Dikshit A.K. (2012), Treatment of Municipal Landfill Leachate by Oxidants, American Journal of Environmental Engineering, 2, 1-5

Shiying Y., Ping W., Xin Y., Guang W., Wenyi Z. and Liang S. (2009), A novel advanced oxidation process to degrade organic pollutants in wastewater: Microwave-activated persulfate oxidation, Journal of Environmental Sciences, 21, 1175-1180

Solid Waste Management Council (SWMC), Annual report of Khan Younis and Deir AL-balah governorates, 2012.

Standard Methods for the Examination of Water and Wastewater, APHA, WPCF, AWWA, 21st ed., American Public Health Association (APHA), Washington, DC, 2005.

Tan C., Gao N., Chu W. and Li C. and Templeton M.R (2012), Degradation of diuron by persulfate activated with ferrous ion, Separation and Purification Technology, 95, 44-48.

Tatsi A., Zouboulis A.L., Matiss K.A. and Samaras P. (2003), Coagulation-flocculation pre-treatment of sanitary landfill leachates, Chemosphere, 53, 737-747.

Trebouet D., Schlumpf J.P., Jaouen P. and Quemeneur F. (2001), Stabilized landfill leachate treatment by combined physicochemical-nanofiltration processes, Water Research, 12, 2935-2942.

US EPA (Environmental Protection Agency), Urban Watershed Management Research Terminology, 2005 (http://www.epa.gov/ednnrmrl/ terminology.html).

Welander U. and Henrysson T. (1998), Physical and chemical treatment of a nitrified leachate from a municipal landfill, Environmental Technology, 19, 591-599.

Wu J. J., Wu C.C., Ma H.W. and Chang C.C. (2004), Treatment of landfill leachate by ozone-based advanced oxidation processes, Chemosphere, 54(7), 997-1003.

Zhang H., Zhang D. and Zhou J. (2006), Removal of COD from landfill leachate by electro-Fenton method, Journal of Hazardous Materials B, 135, 106-111. 